УДК 378.035.04:316.772.4]:61

\title{
МАРИНА БИЧКО
}

Вищий державний навчальний заклад «Українська медична стоматологічна академія», м. Полтава

\section{РОЗВИТОК КОМУНІКАТИВНОӤ КОМПЕТЕНТНОСТІ МАЙБУТНЬОГО ЛІКАРЯ ЯК СКЛАДНИКА ЙОГО ПРОФЕСІЙНОЇ ГОТОВНОСТІ}

\begin{abstract}
Розглянуто сутність комунікативної компетентності майбутнього лікаря як одного із важливих складників його професійної готовності. З'ясовано можливості її розвитку в процесі навчальної та позанавчальної діяльності студента медичного ЗВО з позицій середовищного підходу, окреслено актуальні напрями дослідження цього явища.
\end{abstract}

Ключові слова: майбутній лікар, медичний заклад вищої освіти, готовність до професійної діяльності, комунікативна компетентність.

Постановка проблеми. Підготовка молодої людини до професійної діяльності залишається однією 3 найактуальніших проблем сучасної освіти. Коло професій, на які існує запит, час від часу змінюється, проте існують серед них ті, що не втратять своєї значущості ні за яких умов, хоча й потребують оновлення підходів як до безпосереднього змісту діяльності фахівця, так і до способів його якісної підготовки.

Так, незмінно важливою для суспільства залишається підготовка медичних працівників, зокрема, лікарів. Майбутні фахівці медичної галузі мають бути підготовлені до роботи як із суто професійної, так і індивідуально-особистісної точки зору. Суспільству потрібні висококваліфіковані, конкурентоспроможні спеціалісти, яким притаманна компетентність, ділова завзятість, здатність приймати самостійні, часто вельми ризиковані рішення. Однак, як показує практика, система професійної підготовки, що існує нині, не повністю забезпечує належну готовність випускників медичних вищих навчальних закладів до практичної діяльності. У сучасному суспільстві до молодих фахівців в області медицини ставляться принципово нові вимоги. Тому логічно буде зауважити, що вдосконалення вимагає як процес навчання у вищій школі, так і формування готовності майбутніх лікарів до професійної діяльності зокрема.

Аналіз досліджень та публікацій. Розглянувши та проаналізувавши наукову літературу, що висвітлює проблеми вищої професійної освіти, можна зробити висновок про те, що готовність до професійної діяльності сьогодні $€$ найважливішим показником кваліфікації молодого спеціаліста. Певні аспекти досліджуваної проблеми вже досить грунтовно розглянуті дослідниками. Так, наукові доробки щодо специфіки професійної праці були представлені О. Абдулліною, Е. Карповою, З. Курлянд, Н. Кічук, Н. Ничкало, А. Семеновою, О. Цокур, Г. Щедровицьким, Р.Хмелюк та ін. Загальні питання професійної готовності особистості висвітлювали С. Геллерштейн, М. Д’яченко, М. Болдирєв, О. Гришнова, А. Столяренко Л. Епштейн, А. Линенко, Т. Сапожнікова, Б. Лихачов, П. Новиков, Л. Пономарьов, П. Смоловік, Л. Кандибович та інші. Загальні питання інноваційних технологій навчання розглядалися В.Кудіним, М. Колядою, В. Нефедовою, І.Богдановою, А. Нісімчуком, В. Мадзігоном, І. Підласим та ін.

Поняття готовності з'явилося в полі зору науковців наприкінці XIX ст. Його появу викликала необхідність моделювання активності особистості в різних сферах життєдіяльності. Науковці (Г.Сміт, В. Томас, Ф.Знавецький, Г. Олпорт та ін.) описували готовність як феномен соціально-ціннісної резистентності людини до зовнішніх та внутрішніх впливів навколишнього середовища в межах регуляції та саморегуляції людини. Далі поняття готовності розглядали на фоні емоційно-вольового, моральнопсихологічного, інтелектуального потенціалу особистості в майбутній професійній діяльності. Науковці К. Дурай-Новакова, Н. Кузьміна, О. Мороз, Г. Костюк, А. Щербаков, Л. Кандибович та М. Дьяченко визначають готовність як вибіркову, прогнозовану активність особистості на етапі її підготовки до діяльності.

Метою статті $\boldsymbol{\epsilon}$ теоретичний аналіз поняття готовності майбутніх лікарів до професійної діяльності в контексті міжособистісної взаємодії з пацієнтом.

Виклад основного матеріалу дослідження. Основне завдання, яке держава ставить перед будь-яким закладом вищої освіти, - це провадити освітню діяльнысть на високому рівні, а отже -забезпечити відмінну професійну готовність майбутніх фахівців.

У педагогічній літературі широкого застосування набуло поняття “професійна готовність”, яке нерідко ототожнюється з поняттям “професійна підготовка” (Професійна освіта..., 2000), і також має декілька значень. Найбільш поширеним $є$ наступне тлумачення: організовувати щось; навчити тому, що необхідно; дати необхідні знання.

У сучасній психолого-педагогічній літературі поняття готовність до виконання діяльності зустрічаємо в різних значеннях. Психологи С. Рубінштейн, Б. Ананьєв визначають готовність як показник здібностей. 
Готовність як якість особистості розглядає К. Платонов; як психічний стан та суттєву ознаку установки розглядають ï Д.Узнадзе та І. Бажанова. Готовність як складне особистісне утворення аналізує 3 психологічної точки зору Ю. Гільбух, з педагогічної -Л. Кондрашова. Готовність як систему, яка складається 3 мотиваційного, змістовно-процесуального та виконавчого компонентів, розглядають О. Мороз та В. Сластьонін.

Деякі вчені вважають, що готовність людини до певних видів діяльності можна виховувати (Л. Кондрашова), однак більшість схиляється до думки, що вона все ж таки формується (В. Дорохіна, I. Равикович, С. Коришенко, А. Линенко, Є. Шевчук).

У своїй науковій праці В. Жукова позиціонує готовність як властивість особистості; ця властивість розвивається в результаті накопичення життєвого досвіду, який, в свою чергу, базується на формуванні позитивного ставлення до певного виду діяльності, а також усвідомлення мотивів і потреб. (Жукова, 2011)

I. Ковальська визначає, що готовність - стійке психологічне утворення, що забезпечує здатність людини до успішного виконання завдань (Ковальська, 2009).

В. Крутецький розглядає готовність як синтез якостей особистості, які визначають, чи придатна особа до діяльності в цілому (Крутецкий, 1972).

За визначенням К. Дурай-Новакової, професійна готовність є не лише результатом, але й метою професійної підготовки, початковою та основною умовою ефективної реалізації можливостей кожної особистості. Вчена пов'язує професійну готовність зі спрямованістю на професійну діяльність та стійкими установками на працю (Дурай-Новакова, 1983). Стійкість, стабільність та якість професійної діяльності обумовлюється особливостями психологічної готовності фахівця.

Дослідниця С. Поплавська доводить, що «готовність особистості до професійної діяльності $\epsilon$ інтегрованим системним утворенням, як цілеспрямоване самовираження особистості, яке охоплює їі переконання, погляди, мотиви, почуття, ставлення до діяльності або установку (для ситуативної готовності), а також вольові та інтелектуальні якості, знання про предмет і засоби дії, навички і вміння їх практичного застосування та спрямування на певну поведінку» (Поплавська, 2007, с. 8).

М. Дьяченко і Л. Кандибович вважають, що до структури готовності до професійної діяльності входять такі складові (Дьяченко, Кандыбович, 1976):

- необхідні професійні знання, уміння та навички;

позитивне ставлення до того чи іншого виду діяльності, адекватні щодо них риси характеру, здібності, темперамент і мотиви;

- стійкі професійно важливі особливості психічних процесів: сприймання, мислення;

- емоційні та вольові процеси.

Так, у структурі особистісної готовності С.Д.Поплавська виокремила чотири компоненти, що перекликаються з класифікацією М. Дьяченка і Л. Кандибовича. До них відносяться: мотиваційний (стійка внутрішня спрямованість на певний тип діяльності), емоційний (позитивне ставлення до діяльності), особистісний (здатність до професійної рефлексіі) та професійний (володіння професійно важливими здібностями) (Поплавська, 2007, с.18-19).

Такі різні означення готовності до професійної діяльності зумовлені, насамперед, специфікою структури діяльності, яка вивчається в кожному окремому випадку, і розбіжністю теоретичних підходів дослідників до розуміння її природи та сутністю.

О.Дмитрієва у готовності молодих спеціалістів до професійної діяльності виділяє комунікативну компетентність як невід'ємну складову. До складу комунікативної компетентності дослідниця включає динамічність і адекватність встановлення контакту, подолання боязні спілкування з аудиторією, організацію спілкування як співробітництво та розвиток мовленнєвих форм спілкування (Дмитриева, 1997).

Комунікативна компетентність лікаря грунтується на знаннях та чуттєвому досвіді, здатності орієнтуватися в ситуаціях професійного спілкування, розумінні мотивів, інтенції, стратегії поведінки, фрустрації як своїх власних, так і партнерів по спілкуванню, рівні освоєння технології та психотехніці спілкування. Відповідно до змісту, форм та функцій спілкування, комунікативна компетентність лікаря має охоплювати такі сфери:

- компетентність у здійсненні перцептивної, комунікативної та інтерактивної функцій спілкування;

- компетентність у реалізації, насамперед, суб'єкт-суб'єктної взаємодії з партнерами по спілкуванню (зрозуміло, що спілкування за типом розпоряджень, наказів, інструкцій, вимог тощо (суб'єкт-об'єктна модель взаємодії) також має бути освоєна;

- компетентність у розв’язанні як продуктивних, так і репродуктивних завдань спілкування;

- компетентність у реалізації як поведінкового, операційно-інструментального, так і особистісного, глибинного рівня спілкування.

Визначальну сторону комунікативної компетентності лікаря в сучасних умовах становить компетентність саме в суб'єкт-суб'єктному спілкуванні, у вирішенні продуктивних завдань, в оволодінні глибинним, особистісним рівнем спілкування з іншими людьми (Філоненко, 2008, с. 130]. 
Для лікарів усіх, без виключення, спеціальностей є дуже важливою проблема співпраці лікаря та хворого. Однак вчені відзначають парадоксальний факт, що частота випадків недостатньої співпраці хворого з лікарем має тенденцію до зростання паралельно прогресу в області діагностики та лікування, значною мірою нівелюючи досягнення останніх (Блохіна та ін., 2003).

За визначенням Л.Орбан-Лембрик, взаємодія - взаємозалежний обмін діями, організація людьми взаємних дій, спрямованих на реалізацію спільної діяльності (Орбан-Лембрик, 2003). Взаємодія лікаря та пацієнта спрямована на досягнення єдиної мети - діагностування захворювання, лікування пацієнта та його одужання. Зазвичай, основним мотивом зустрічі та бесіди стає виникнення у пацієнта проблем зі здоров'ям, а спілкування лікаря та пацієнта є вимушеним спілкуванням, що накладає відбиток на його перебіг.

Уміння спілкуватись із хворими належить до найцінніших якостей лікаря будь-якої медичної спеціальності і визначає ефективність лікувально-діагностичного процесу, ступінь задоволеності пацієнта наданою йому допомогою, а також оцінку професійності фахівця.

Одним із показників надання якісної медичної допомоги $є$ відсутність конфліктів між пацієнтом та лікарем. Нині медичну допомогу сприймають як послугу, яку надає заклад охорони здоров’я. Тому цілком логічно, що пацієнт, прийшовши на консультацію або розпочавши лікування, має певні очікування, тобто створює ідеалізований образ лікаря та лікувального процесу загалом.

Зі свого боку, лікар теж має певні очікування щодо того, як хворий має поводитись, як він реагуватиме на запропоноване лікування. Ці уявлення грунтуються на життєвому досвіді кожного з них та соціальних нормах. Невідповідність між реальністю та очікуваннями дуже часто стає причиною конфліктів. Пацієнти можуть виражати незадоволення організацією медичної допомоги, кваліфікацією медичного персоналу, відсутністю необхідного обладнання, санітарними умовами у закладі тощо. При цьому досить часто конфлікти виникають саме на психологічному рівні і пов'язані з поведінкою кожної із сторін. Наприклад, як зауважує 0. Чубко,пацієнт суб'єктивно може сприймати ділове спілкування як байдужість, а привітність - як фамільярність.

Нездатність лікаря повною мірою пояснити важливість лікування, викласти основні його засади 3 урахуванням мінімізації ризиків та очікуваного позитивного ефекту, розвінчати хибні уявлення про хворобу, брак часу при роботі з пацієнтом, надмірна суворість до хворого, відсутність у хворого високого ступеня довіри до спеціаліста також є причинами недотримання схем лікування (Кострікова, 2012).

Всі ці неприємні моменти в спілкуванні лікаря та пацієнта частіше за все виливаються у пряму чи приховану відмову від призначеного лікування.

Враховуючи все вищесказане, лікар повинен чітко усвідомлювати ті процеси, які відбуваються під час взаємодії з пацієнтом упродовж лікування, так само, як і відслідковувати свої власні стани, здійснювати самоконтроль, що повинно знайти відбиток у процесі його професійної підготовки.

Висновки. Готовність майбутніх лікарів до професійної діяльності $\epsilon$ складним багаторівневим утворенням, яке виявляється у мірі відповідності особистості вимогам до певної діяльності, а наявність готовності до діяльності є обов'язковою передумовою здійснення самої діяльності.

Комунікативна компетентність майбутнього лікаря передбачає засвоєння ним правил і норм усної та писемної мови, уміння користуватися ними в різних життєво-професійних ситуаціях, це один 3 важливих складників професійної компетентності фахівців медичного профілю. Подальшого дослідження потребує комунікативна компетентність лікаря у відповідності з типовими ситуаціями спілкування з пацієнтами в умовах сучасної організації медичної допомоги в Україні.

\section{Список використаних джерел}

Професійна освіта: словник: навч. посіб. / [уклад. С. У. Гончаренко та ін.; за ред. Н. Г. Ничкало.] - К.: Вища школа, 2000. $390 \mathrm{c}$.

Жукова В. Ф.Психолого-педагогический анализ категории “психологическая готовность” / В. Ф. Жукова // Вестник Филиала Российского государственного университета в г. Сургуге, 2011. - Т. 4. - № 5. - С. 32-35. - Серія "Педагогические науки"

Ковальська I. Е. Формування психологічної готовності членів громадських формувань до охорони державного кордону : автореф. дис. .... канд. псих. наук: 19.00.09 / Ірина Едуардівна Ковальська. - Хмельницький, 2009. - 23 с.

Крутецкий В. А. Основы педагогической психологии / В. А. Кругецкий. - М. : Просвещение, 1972. - 255c.

Дурай-Новакова К. М. Формирование профессиональной готовности студентов к педагогической деятельности: автореф. дис. ... д-ра пед. наук: 13.00.01 / Кристина Мечиславовна Дурай-Новакова. - Москва, 1983. - 32с.

Поплавська С.Д. Формування готовності студентів медичних коледжів до комунікативної взаємодії у професійній діяльності: автореф. дис. ... канд. пед. наук: 13.00.04 / Світлана Дмитрівна Поплавська. - Житомир, 2009. - 22 с.

Дьяченко М. И. ІІихологические проблемы готовности к деятельности / М. И. Дьяченко, Л. А. Кандыбович;-Минск: БГУ, 1976. $-167 \mathrm{c}$.

Дмитриева О. Б. Формирование психологической готовности молодых специалистов к профессиональной деятельности: автореф. дис. ... канд. пед. наук: 19.00.13 / Ольга Борисовна Дмитриева. - Москва, 1997. - 18 с.

Педагогика: учеб. пособие / В. А. Сластенин, И. Ф. Исаев, И. А. Мищенко и др.. - М.: Школа_Пресс, 2000. -512 с. 
Медицинское образование в мире и в Украине / Ю. В. Поляченко, В. Г. Передерий, А. П. Волосове, В. Ф. Москаленко и др. -Х.: ИПП «Контраст», 2005. - 464 с.

Філоненко М. Психологія спілкування: навч. посібник./ - К.: Центр учбової літератури, 2008.- 224 с ст..130

Загальна та медична психологія: практикум / В. П. Блохіна, І. С. Вітенко, І. Д. Спіріна, Г. І. Лисиця, Д. Ф. Кетков. - Д.: АРТПРЕС, 2002. - $176 \mathrm{c}$.

Орбан-Лембрик Л. Е. Соціальна психологія: посіб. / Л. Е. Орбан-Лембрик. - К.: Академвидав, 2003. — 448 с.

Чубко О. Б. Конфліктні ситуації у роботі лікаря як одна з причин професійного вигорання [Електронний ресурс] // Режим доступу: https://neuronews.com.ua/ua/issue-article-1584/Konfliktni-situaciyi-u-roboti-likarya-yak-odna-z-prichinprofesiynogo-vigorannya\#gsc.tab $=0$

Кострікова Ю.А. Питання взаємодії лікаря і пацієнта в процесі терапії / Ю. А. Кострікова // Актуальні проблеми сучасної медицини. - 2012. - Т. 12, Вип. 3. - С. 180-182.

\section{References}

Profesijna osvita: slovnik: navch. posib. / [uklad. S. U. Goncharenko ta in.; za red. N. G. Nichkalo.] - K.: Visha shkola, 2000. - 390 s.

Zhukova, V. F. Psihologo-pedagogicheskij analiz kategorii "psihologicheskaya gotovnost" / V. F. Zhukova // Vestnik Filiala Rossijskogo gosudarstvennogo universiteta v g. Surgute, 2011. - T. 4. - № 5. - S. 32-35. - Seriya "Pedagogicheskie nauki"

Kovalska, I. E. Formuvannya psihologichnoyi gotovnosti chleniv gromadskih formuvan do ohoroni derzhavnogo kordonu : avtoref. dis. ... kand. psih. nauk: 19.00.09 / Irina Eduardivna Kovalska. - Hmelnickij, 2009. - 23 s.

Kruteckij, V. A. Osnovy pedagogicheskoj psihologii / V. A. Kruteckij. - M. : Prosveshenie, 1972. - 255s.

Duraj-Novakova, K. M. Formirovanie professionalnoj gotovnosti studentov k pedagogicheskoj deyatelnosti: avtoref. dis. ... d-ra ped. nauk: 13.00.01 / Kristina Mechislavovna Duraj-Novakova. - Moskva, 1983. - 32s.

Poplavska, S. D. Formuvannya gotovnosti studentiv medichnih koledzhiv do komunikativnoyi vzayemodiyi u profesijnij diyalnosti: avtoref. dis. ... kand. ped. nauk: 13.00.04 / Svitlana Dmitrivna Poplavska. - Zhitomir, 2009. - 22 s.

Dyachenko, M. I. Ilsihologicheskie problemy gotovnosti k deyatelnosti / M. I. Dyachenko, L. A. Kandybovich; - Minsk: BGU, 1976. $-167 \mathrm{~s}$.

Dmitrieva, O. B. Formirovanie psihologicheskoj gotovnosti molodyh specialistov k professionalnoj deyatelnosti: avtoref. dis. ... kand. ped. nauk: 19.00.13 / Olga Borisovna Dmitrieva. - Moskva, 1997. - 18 s.

Pedagogika: ucheb. posobie / V. A. Slastenin, I. F. Isaev, I. A. Mishenko, E. N. Shiyanov. - M.: Shkola_Press, 2000. -512 s. Medicinskoe obrazovanie v mire i v Ukraine / Yu. V. Polyachenko, V. G. Perederij, A. P. Volosove, V. F. Moskalenko i dr. H.: IPP «Kontrast», 2005. - $464 \mathrm{~s}$.

Filonenko, M. Psihologiya spilkuvannya: navch. posibnik./ - K.: Centr uchbovoyi literaturi, 2008.-224 c st..130

Zagalna ta medichna psihologiya: praktikum / V. P. Blohina, I. S. Vitenko, I. D. Spirina, G. I. Lisicya, D. F. Ketkov. - D.: ARTPRES, 2002. $-176 \mathrm{~s}$.

Orban-Lembrik, L. E. Socialna psihologiya: posib. / L. E. Orban-Lembrik. - K.: Akademvidav, 2003. — 448 s.

Chubko, O. B. Konfliktni situaciyi u roboti likarya yak odna z prichin profesijnogo vigorannya [Elektronnij resurs] // Rezhim dostupu: $\quad \mathrm{https}: / /$ neuronews.com.ua/ua/issue-article-1584/Konfliktni-situaciyi-u-roboti-likarya-yak-odna-z-prichinprofesiynogo-vigorannya\#gsc.tab $=0$

Kostrikova, Yu.A. Pitannya vzayemodiyi likarya i paciyenta v procesi terapiyi / Yu. A. Kostrikova // Aktualni problemi suchasnoyi medicini. - 2012. - T. 12, Vip. 3. - S. 180-182.

\section{BYCHKO M.}

Higher state educational institution "Ukrainian Medical Stomatological Academy", Poltava, Ukraine

\section{DEVELOPMENT OF COMMUNICATIVE COMPETENCE OF THE FUTURE PHYSICIAN AS COMPLETE OF ITS PROFESSIONAL READINESS}

The essence of communicative competence of the future doctor as one of the important components of his professional readiness is considered. The possibilities of its development in the process of educational and non-initial activity of the student of a medical institution of higher education from the standpoint of the environmental approach are determined, the actual directions of research of this phenomenon are outlined. The readiness of future doctors for professional activity is considered as a complex multilevel entity, which manifests itself as a person's compliance with the requirements for certain activities, and availability of readiness for activities is a prerequisite for the implementation of the activity itself.

The communicative competence of the future physician implies the assimilation of the rules and norms of oral and written language, the ability to use them in various life-professional situations. It is communicative competence - one of the basic characteristics of the professional competence of medical specialists. Further research requires the communicative competence of a doctor in accordance with the typical situations of communication with patients in the context of a modern organization of medical care in Ukraine.

Keywords: future physician, medical institution of higher education, readiness for professional activity, communicative competence.

Стаття надійшла до редакції 14.03.2018 р. 